\title{
INFLUENCE OF BREED, SEX AND GROWTH HORMONE AND HALOTHANE GENOTYPES ON CARCASS COMPOSITION AND MEAT QUALITY TRAITS IN PIGS
}

\author{
M.M. FRANCO ${ }^{1,2,4}$, R.C. ANTUNES ${ }^{1}$, M. BORGES ${ }^{3}$, E.O. MELO $^{2}$ and \\ L.R. GOULART ${ }^{1}$ \\ ${ }^{1}$ Laboratório de Genética Molecular \\ Instituto de Genética e Bioquímica \\ Universidade Federal de Uberlândia \\ Campus Umuarama \\ Bloco 2E, Sala 24, Uberlândia, MG, Brazil, CEP 38400-902 \\ ${ }^{2}$ EMBRAPA Genetic Resources and Biotechnology \\ Av. W/5 Norte Final \\ PBI, Sala 7B, Brasilia, DF, Brazil, CEP 70770-900 \\ ${ }^{3}$ Progênie Tecnologia em Melhoramento \\ Rua Eduardo Marquez 909/1502 \\ Uberlândia-MG, Brazil, CEP 38400-442
}

Accepted for Publication March 20, 2007

\begin{abstract}
The objective of this study was to verify the influence of the growth hormone (GH) and halothane (Hal) genotypes, breed and sex on carcass and meat quality. Ninety-six pigs (Piétrain, Large White and Landrace) were dissected. For each breed, 16 were noncastrated males and 16 were females. The Piétrain animals presented the greatest lean meat percentage, the heaviest ham and shoulder and the lightest belly weight and fat thickness. Landrace presented the heaviest belly. Females presented the greatest drip loss; $\mathrm{L}^{*}, \mathrm{~b} *$ and fat thickness; the heaviest ham and loin; and the lightest shoulder and tenderloin. Hal-NN and $\mathrm{Nn}$ presented greater loin weight than $\mathrm{nn}$ animals. $\mathrm{Nn}$ animals presented smaller belly weight than homozygotes. The nn animals presented greater drip loss than $\mathrm{NN}$ and $\mathrm{Nn}$, and greater lean meat than $\mathrm{NN}$. Interestingly, $\mathrm{GH}-\mathrm{D}_{2} \mathrm{D}_{2}$ animals also showed higher drip loss than those with $\mathrm{D}_{l} \mathrm{D}_{l}$ genotype. This investigation presents relevant associations between important economic traits and specific $\mathrm{GH}$ and $\mathrm{Hal}$ genotypes.
\end{abstract}

${ }^{4}$ Corresponding author. TEL: +55-61-3448-4774; FAX: +55-61-3340-3658; EMAIL: mfranco@ cenargen.embrapa.br 


\section{PRACTICAL APPLICATIONS}

The identification of new molecular markers related to pig production has been increasing in importance, especially when these markers are related to carcass and meat quality traits, which are difficult to predict. When a marker is intensively used in a selection program, it reaches fixation, so it is important to identify new markers to replace it. This work shows, for the first time, the association of a GH polymorphism with an important meat quality trait and reinforces the possibility of its use in programs of marker-assisted selection.

\section{INTRODUCTION}

Important economic traits in the pig industry are frequently ruled by several pleiotropic genes, and also influenced by the environment. Any given gene involved in a relevant biochemical pathway can be settled as a candidate gene in genetic markers mining. Once a DNA marker has been shown to be associated with variation in the target trait, then it can be used to genetically type young animals for preselection before performance testing (Plastow et al. 2005).

The four major properties that determine pig meat quality are technological, sensorial, hygienic and nourish properties (Sellier 1995). Cameron (1993) and Moller and Iversen (1993) postulated that meat quality, distinctively of meat quantity, is a complex concept hardly to be defined by a simple and an easy way. This complexity is exacerbated in the pig industry because of the great variety of meat processing methods, which require distinct meat quality traits. Among the factors influencing pig meat quality, especially the pale, soft and exudative (PSE) condition, the genetic background, preslaughter handling, slaughter and chilly methods are very important. Sex, breed and major gene effects are relevant factors. However, the effect of breed can be mistaken for the effect of major genes (de Vries et al. 2000).

The most important genetic alteration that influences porcine production is the porcine stress syndrome (PSS). Christian (1972) established that PSS is caused by a recessive mutation with an incomplete penetrance trait. This gene codifies a protein that makes part of a calcium-channel in the endoplasmatic reticulum of skeletal muscle cells (Fujii et al. 1991). The correlation between PSS and PSE is well established in pigs. The PSS happens when the mutant (halothane [Hal]) animals are subjected to a stressful condition before being slaughtered. The economical loss in the pig industry caused by PSS and, consequently, PSE meat is around several millions of dollars (Swatland 1995).

The association of growth hormone $(G H)$ gene polymorphisms with carcass traits has been frequently reported in the literature. Vize and Wells 
(1987) showed that the swine $G H$ is a single copy gene, and localizes in chromosome 12. The great influence exerted by GH in relevant traits of meat quality has been stimulating several investigations about molecular polymorphisms in the $G H$ gene (Schellander et al. 1994). Polymorphisms of the $G H$ gene are associated with performance and carcass composition traits in distinct pig breeds (Geldermann et al. 1996; Knorr et al. 1997; Nielsen and Sorensen 1998; Putnova et al. 2001; Franco et al. 2005). Campbell et al. (1989) provided GH to castrated males, females and boars, and observed increased growth rate and food intake conversion, higher meat protein and water content, although with reduced fat. Other candidate genes have been studied and can be correlated with carcass composition and meat quality traits. Enfält et al. (2006) and Lindahl et al. (2006) showed the effects of Rendement Napole $(R N)$ gene on carcass composition and meat color characteristics, respectively.

About $10-70 \%$ of meat quality variation can be caused by genetic background (Baas 1996; Socha 1997). In pigs, the estimated heritability for traits such as color, intramuscular fat (IMF), softness and drip ranges from moderate to high, suggesting that there is a good feasibility for their selection (Baas 1996). The heritability values of $0.16,0.21,0.28,0.16$ and 0.26 were found for $\mathrm{pH}_{1}, \mathrm{pH}_{\mathrm{u}}$, color (CIE $L^{*}$ value), drip loss and softness, respectively (Sellier and Monin 1994; Sellier 1995, 1998).

Considering the significant physiological effects of $\mathrm{Hal}$ and $\mathrm{GH}$ genes on swine growth rate, the association between these two gene polymorphisms with carcass composition and meat quality traits in three pig breeds was analyzed.

\section{MATERIALS AND METHODS}

\section{Animals and Treatments}

Ninety-six pigs from three breeds (Piétrain, Large White and Landrace) with 147 days of age were used in this study. Each breed consisted of a group of 16 males and 16 females provided by Granja Rezende S/A, Uberlândia, Brazil. The animals were slaughtered at the Rezende Alimentos S/A abattoir after a 50-min transportation during the night, and $18 \mathrm{~h}$ of fasting. The animals were slaughtered in accordance with the Brazilian legislation. Briefly, pigs were electrically stunned (thorax and head) and exsanguinated in the horizontal position. After slaughtering, carcasses were split into two halves, eviscerated and chilled according to standard commercial practices.

\section{Carcass Dissection}

Two-half carcasses were dissected $24 \mathrm{~h}$ after slaughtering to determine the lean meat percentage, according to the new EU reference dissection 
method (Walstra and Merkus 1995). According to this method, the carcass is divided into the following: leg, loin, neck, head + cheek, front shank + front foot, hind shank + hind foot, tenderloin, shoulder, jaw, belly, ventral part of belly and to ventral part of belly. Before the dissection, the carcass was prepared by removing the genitalia rests, diaphragm and tail. The spinal cord and brain were also removed. Only the ham, loin, shoulder and belly were dissected, separating the skin, fat, bones and muscles. The least square means shown in Table 1 represent only the amount of meat from each part of the carcass, as cited before. Data on fat thickness $(\mathrm{mm})$ were measured in the $\mathrm{P} 2$ point.

\section{Meat Quality}

Analyses of drip loss, color, texture and IMF were carried out in semimembranosus muscle (SM) samples, which is an important part of the ham. The SM was withdrawn from the ham removed from the left-half of the chilled carcass, according to protocols of the Rezende Alimentos S/A laboratory. For the drip loss analysis, two muscle samples of $2.5-\mathrm{cm}$ thickness were withdrawn from each animal. These samples were removed, by perpendicularly oriented cuts in relation to the muscle fibers, weighted, hanged and wrapped into a drip loss plastic container. After this procedure, the samples were stored at $4 \mathrm{C}$ for $48 \mathrm{~h}$, then removed from the container, carefully dabbed and weighed. Drip loss was estimated by calculating the difference between the initial and the final weight of the muscle samples. For the color analysis, the meat was homogenized by grinding, and a sample was submitted for measurement of color and lightening according to the reflectance coordinates CIE $L^{*}$, $a^{*}, b^{*}$ in $560 \mathrm{~nm}$ (CIE 1976), using the UltraScan XE spectrophotometer (HunterLab, Reston, VA). The texture analyses were carried out $24 \mathrm{~h}$ after slaughter with chilled carcass, using the TA.XT2 texture analyzer (Stable Micro Systems Ltd., Godalming, U.K.). For the texture analysis, samples with $1.8 \mathrm{~cm}$ of thickness were perpendicularly cut across the muscle fiber orientation. The samples were compressed $5 \mathrm{~mm}$ with a flat, $50-\mathrm{mm}$ plate, and the values were shown in kilograms. For the IMF analysis, $4.0 \mathrm{~g}$ of meat samples was taken off from the meat surface by transversal cuts in relation to the muscle fibers. Then, the samples were homogenized by grinding, and IMF content was measured by extraction with dichloromethane (Merck, Whitehouse Station, NJ) as solvent using the LAB Wave 9000 and FAS-9001 (CEM Innovators in Microwave Instrumentation, Matthews, NC) equipment.

\section{Hal and GH Genotyping}

The genomic DNA utilized was isolated from white blood cells (Franco et al. 2003). For the Hal gene genotyping (HAL-1843, as licensed from the 


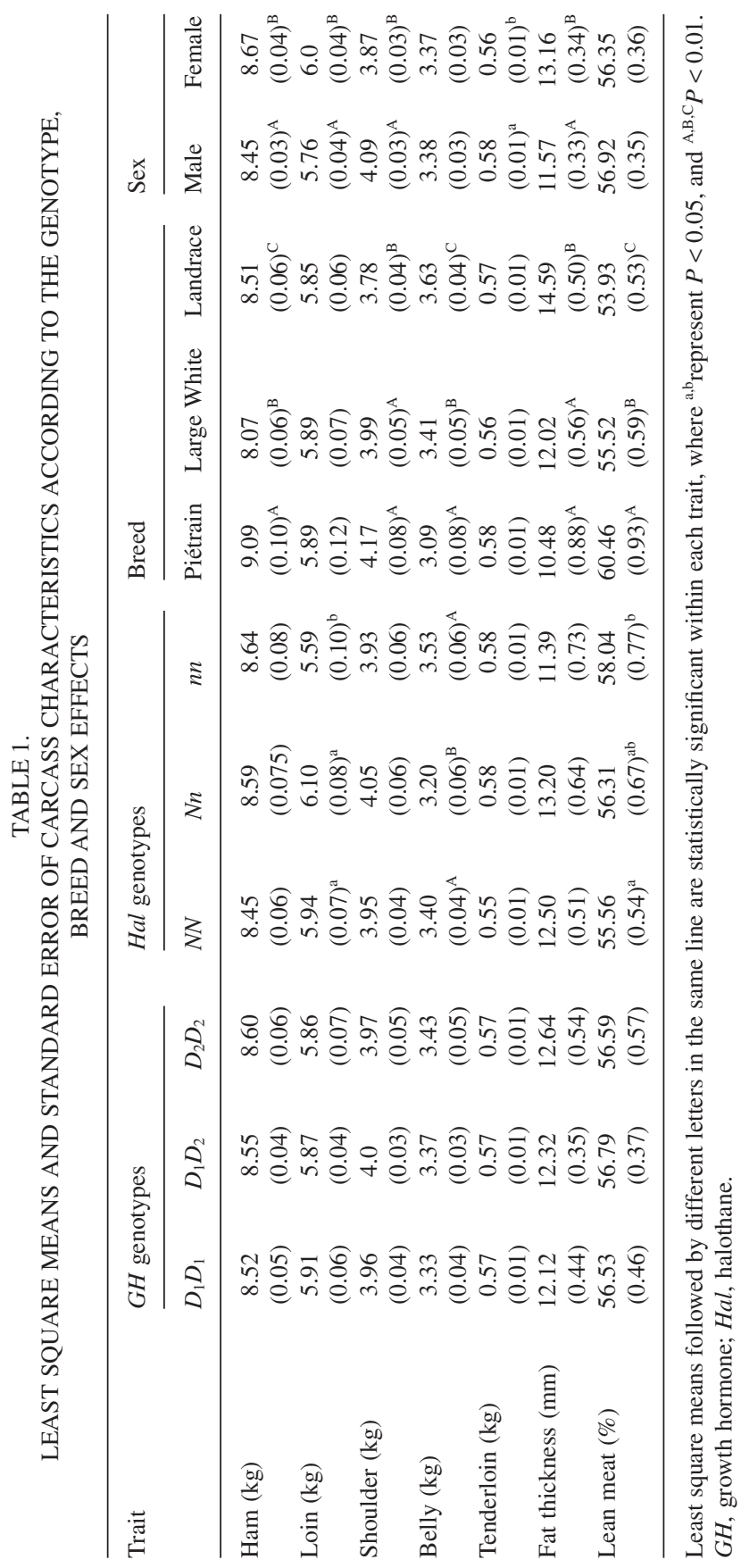


innovations foundation) (Fujii et al. 1991), a pair of primers was designed at the UFU Molecular Genetics Laboratory using the Primer Designer 2.0 program (Scientific and Educational Software, Cary, NC). The primer sequences were: $5^{\prime}$ CCTGGGACATCATCCTTCTG $3^{\prime}$ (forward) and $5^{\prime}$ GGTGGTGGAGGGTTCTAAGC 3' (reverse). Polymerase chain reaction (PCR) was done using 50-150 ng of genomic DNA, $100 \mu \mathrm{M}$ of each dNTP, $0.5 \mu \mathrm{M}$ of each primer, $1 \mathrm{U}$ of Taq polymerase, $2 \mathrm{mM}$ of $\mathrm{MgCl}_{2}$ and enzyme buffer in a final volume of $20 \mu \mathrm{L}$. The amplification conditions were: $95 \mathrm{C}$ for $5 \mathrm{~min}$, prior to 35 cycles of $94 \mathrm{C}$ for $20 \mathrm{~s}, 56 \mathrm{C}$ for $30 \mathrm{~s}$ and $72 \mathrm{C}$ for $30 \mathrm{~s}$, with a final extension at $72 \mathrm{C}$ for $4 \mathrm{~min}$. After amplification, $20 \mu \mathrm{L}$ of the PCR amplicon (282 bp) was digested with $1 \mathrm{U}$ of Hha I/ $/ \mathrm{g}$ DNA during overnight at $37 \mathrm{C}$, and genotyping was determined in a $2.5 \%$ agarose gel electrophoresis stained with ethidium bromide $(10 \mathrm{mg} / \mathrm{mL})$, and photo-documented. Two patterns of alleles were produced: $N$ with $150 \mathrm{bp} / 132 \mathrm{bp}$ fragments, and $n$ with 282 bp.

For the $G H$ gene genotyping, a pair of primers designed by Larsen and Nielsen (1993) was used. PCR reactions consisted of 50-150 ng of genomic DNA, $100 \mu \mathrm{M}$ of each dNTP, $0.5 \mu \mathrm{M}$ of each primer, $1 \mathrm{U}$ of Taq polymerase, $3 \mathrm{mM}$ of $\mathrm{MgCl}_{2}$ and enzyme buffer in a final volume of $20 \mu \mathrm{L}$. The amplification conditions were: $95 \mathrm{C}$ for $3 \mathrm{~min}$, prior to 35 cycles of $95 \mathrm{C}$ for $45 \mathrm{~s}$, 59C for $45 \mathrm{~s}$ and $76 \mathrm{C}$ for $1 \mathrm{~min}$, with a final extension at $76 \mathrm{C}$ for $4 \mathrm{~min}$. After amplification, $20 \mu \mathrm{L}$ of the PCR amplicon (605 bp) was digested with 2-4 U of Dde I overnight at $37 \mathrm{C}$, and genotypic determination was performed as described earlier. Two patterns of alleles were generated: $D_{1}$ with 335,148 and $122 \mathrm{bp}$ fragments, and $D_{2}$ with 457 and $148 \mathrm{bp}$.

\section{Statistical Analysis}

Data were analyzed using the GLM Procedure of SAS (1992). Breed, sex and $\mathrm{Hal}$ and $\mathrm{GH}$ genotypes were used as main effects in the analysis of variance. Each animal was taken as an experimental unit for carcass composition and meat quality data. Two-way interactions were not evaluated, and the carcass weight was used as covariate to correct the trait values, only if the trait was influenced by this covariable. Pair-wise comparisons were performed by the $t$ test. The results are expressed as the mean \pm SEM, with $P$ values $<0.05$ of significance. The general linear model used was assumed to be: $Y_{i j k l m}=\mu+$ $\gamma_{1}\left(X_{i j k l m 1}-X \ldots{ }_{1}\right)+R_{i}+S_{j}+$ genotype $1_{k}+$ genotype $2_{l}+e_{i j k l m}$, where $Y_{i j k l m}$ corresponds to the traits observed, $\mu$ is the population mean of the measurements, $R_{i}$ represents the breeds ( $i=$ Piétrain, Large White or Landrace), $S_{j}$ represents the sex ( $j=$ male or female), genotype $1_{k}$ represents $\mathrm{Hal}$ genotypes $(k=N N, N n$ or $n n)$, genotype $2_{l}$ represents the $G H$ genotypes $\left(l=D_{1} D_{1}, D_{1} D_{2}\right.$ or $\left.D_{2} D_{2}\right), \gamma_{1}$ is the covariate effect ( $X_{i j k l m l}$ carcass weight) and $e_{i j k l m}$ is the random error effect 
of the $i j$ th pig, with normal distribution, and independently distributed with zero mean and variance $\sigma^{2}$. The least square means of the traits and the standard errors for each main effect are shown in Tables 1 and 2. The haplotype formation and allelic frequencies for each breed and sex are shown in Table 3.

\section{RESULTS AND DISCUSSION}

Regarding meat quality, the Hal genotypes showed a significant influence only over drip loss (Table 2). The $n n$ animals showed the largest drip loss, which is considered an undesirable influence of the $\mathrm{Hal}$ gene over meat quality traits. This result is in disagreement with those of Bridi et al. (2003) and Band et al. (2005), who found differences in drip loss measurements between $N N$ and $N n$ crossed animals. The $N n$ animals presented larger drip loss. These different results can suggest that preslaughter handling used in this experiment was more efficient to minimize the detrimental effect of the $n$ allele in $\mathrm{Nn}$ animals. In terms of color parameters, the $\mathrm{Hal}$ gene did not affect $L^{*}, a^{*}$ and $b^{*}$ values, despite the fact that the influence of the gene on meat color, and consequently on PSE meat production, has been well established. Other genes can affect these parameters. Lindahl et al. (2006) studying the $R N$ gene in crossed animals (Hampshire boars and Landrace $\times$ Yorkshire dams) showed that $R N^{*}$ animals presented higher $L^{*}, a^{*}$ and $b^{*}$ values than $r n^{+}$animals. When the carcass composition was considered, the $n n$ animals presented higher lean meat percentage than the $N N$ animals (Table 1), which is in accordance with the $\mathrm{Hal}$ gene effect over lean meat production. The $n n$ animals also presented the least loin weight. In relation to the belly weight, Antunes et al. (2001), working with crossbred progenies, did not find any difference between $N N$ and $N n$ animals. However, in this work, the $N n$ animals showed less belly weight than $N N$ and $n n$ pigs (Table 1). This discrepancy is probably because of the different genetic backgrounds between breeds. When meat quality parameters were evaluated, the detrimental effect of $\mathrm{Hal}$ gene became evident. However, the effect of $\mathrm{Hal}$ is positive when the production of lean meat is the main objective. The major goal of the pig industry is to produce leaner animals, with higher meat quality. This shows the importance of the knowledge about the qualities of each pig breed or line to best explore each of them, and therefore produce crossbred animals with the optimized attributes to the pig industry.

Differences of drip loss, $L^{*}$ and $b^{*}$ values were found between the genders (Table 2). Female animals presented higher drip loss than the males, contradicting the data presented by Enfält et al. (1997), who studied different breeds, Hampshire and Yorkshire. This discrepancy may be caused by the differences in the genetic backgrounds between breeds or by differences in pig 


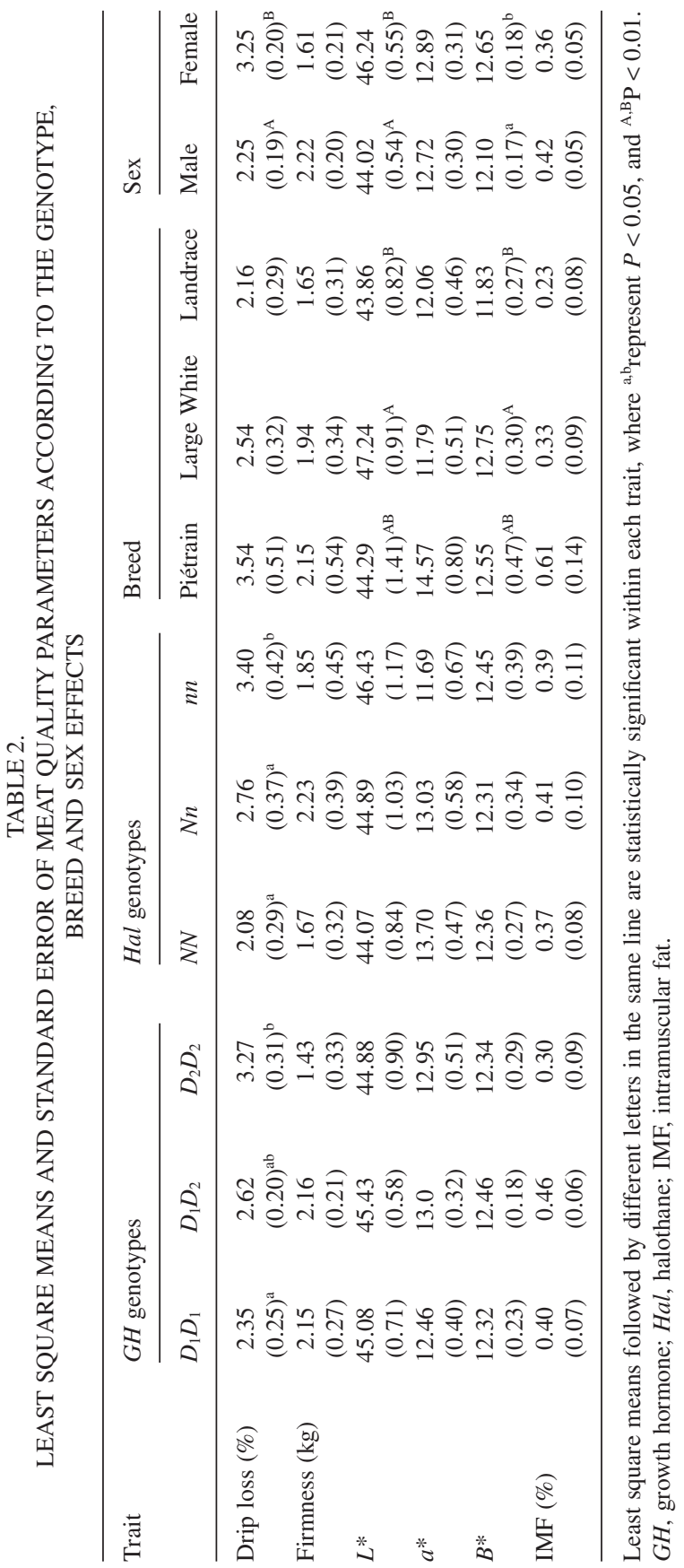


TABLE 3.

GENOTYPE FORMATION WITH GROWTH HORMONE $(G H)$ AND HALOTHANE $(\mathrm{Hal})$ GENE POLYMORPHISMS, THE ALLELIC FREQUENCIES AND THEIR DISTRIBUTION WITHIN EACH BREED AND SEX

\begin{tabular}{|c|c|c|c|c|c|c|c|c|}
\hline & & \multicolumn{3}{|c|}{$G H$ genotypes } & \multicolumn{4}{|c|}{ Allelic frequencies } \\
\hline & & \multirow[t]{2}{*}{$D_{1} D_{1}$} & \multirow[t]{2}{*}{$D_{1} D_{2}$} & \multirow[t]{2}{*}{$D_{2} D_{2}$} & \multicolumn{2}{|l|}{ Hal } & \multicolumn{2}{|l|}{$G H$} \\
\hline & & & & & $N$ & $n$ & $D_{1}$ & $D_{2}$ \\
\hline \multirow{4}{*}{$\begin{array}{l}\text { Piétrain } \\
\text { Hal genotypes }\end{array}$} & & & & & & & & \\
\hline & $N N$ & * & * & * & 0 & 1.00 & 0.72 & 0.28 \\
\hline & $\mathrm{Nn}$ & $*$ & * & $*$ & & & & \\
\hline & $n n$ & 16 & 14 & 02 & & & & \\
\hline \multirow{4}{*}{$\begin{array}{l}\text { Large White } \\
\text { Hal genotypes }\end{array}$} & & & & & & & & \\
\hline & $N N$ & $*$ & 12 & 09 & 0.81 & 0.19 & 0.25 & 0.75 \\
\hline & $\mathrm{Nn}$ & * & 04 & 06 & & & & \\
\hline & $n n$ & $*$ & $*$ & 01 & & & & \\
\hline \multicolumn{9}{|l|}{ Landrace } \\
\hline \multirow[t]{3}{*}{ Hal genotypes } & $N N$ & 10 & 09 & 02 & 0.78 & 0.22 & 0.69 & 0.31 \\
\hline & $\mathrm{Nn}$ & 04 & 03 & 01 & & & & \\
\hline & $n n$ & 01 & 02 & $*$ & & & & \\
\hline \multicolumn{9}{|l|}{ All animals } \\
\hline \multirow[t]{3}{*}{ Hal genotypes } & $N N$ & 10 & 21 & 11 & 0.535 & 0.465 & 0.55 & 0.45 \\
\hline & $\mathrm{Nn}$ & 04 & 07 & 07 & & & & \\
\hline & $n n$ & 17 & 16 & 03 & & & & \\
\hline \multicolumn{9}{|l|}{ Male } \\
\hline \multirow[t]{3}{*}{ Hal genotypes } & $N N$ & 05 & 08 & 09 & 0.542 & 0.458 & 0.552 & 0.448 \\
\hline & $\mathrm{Nn}$ & 02 & 02 & 04 & & & & \\
\hline & $n n$ & 12 & 05 & 01 & & & & \\
\hline \multicolumn{9}{|l|}{ Female } \\
\hline \multirow[t]{3}{*}{ Hal genotypes } & $N N$ & 05 & 13 & 02 & 0.520 & 0.48 & 0.552 & 0.448 \\
\hline & $\mathrm{Nn}$ & 02 & 05 & 03 & & & & \\
\hline & $n n$ & 05 & 11 & 02 & & & & \\
\hline
\end{tabular}

* Absence of genotypic combination.

handling before and after slaughtering. In this work, it was observed that the female meat showed more similarity with PSE meat than the male, because it presented higher drip loss, $L^{*}$ and $b^{*}$ values. Water loss is one of the major factors that determine meat quality in the pig industry. Moreover, meat color is responsible for the increasing repulse of pork meats in market stores (Soares et al. 1998), in spite of not being a relevant trait for meat quality definition. Gender also affects the carcass composition traits (Table 1). Females showed higher fat thickness and ham and loin weight than males, but males presented higher shoulder and tenderloin weight. These results are in agreement with those of Antunes et al. (2001) except for the loin weight. These authors found 
higher tenderloin weights in females, and higher fat thickness in males, but there were no differences in ham or shoulder between them. Based on these results, Antunes et al. (2001), working with crossbred animals, concluded that females produced better carcass composition than males. The higher shoulder weight and smaller fat thickness found in males in this study may be caused by the testosterone effect; however, it has not been tested. Despite the fact that females showed worse meat quality, with higher drip loss, $L^{*}$ and $b^{*}$ values, and fat thickness, they showed a better carcass composition because the ham and loin cuts are the ones with higher economical yield in the pig industry.

Regarding meat quality within each breed, Large White animals showed higher $L^{*}$ and $b^{*}$ values than the Landrace (Table 2), in agreement with the national genetic evaluation test results cited in Socha (1997), that showed significant differences among breeds for meat quality traits. However, $L^{*}$ and $b^{*}$ values are not major meat quality parameters for the pig industry. This can be explained by the fact that distinct parts of the same carcass show different color patterns, and even because of the wide variety of meat color patterns found among different parts of the same muscle. In spite of being expected that Piétrain animals would exhibit the worst meat quality for the parameters analyzed, it, surprisingly, did not happen. This unexpected result could have happened probably because of good animal handling before and after slaughtering. These results clearly show the relevance of animal handling to improve meat quality, and consequently, to raise its market price, a goal which is impossible to accomplish with the high prevalence of PSE meat. In relation to carcass composition, Piétrain animals showed the highest lean meat percentage, followed by Large White and Landrace animals (Table 1). Piétrain animals also showed the highest ham weight, followed by Landrace and Large White (Table 1). Landrace animals presented lower shoulder weight than the other two breeds (Table 1), and had the highest belly weight, followed by Large White and Piétrain. Finally, Landrace animals presented the highest fat thickness (Table 1).

When the $G H$ genotypes were evaluated, differences in drip loss measurements were found (Table 2). $D_{2} D_{2}$ animals showed higher drip loss than $D_{1} D_{1}$ animals. In another study, using the same population studied here, $D_{1} D_{2}$ animals presented lowest fat thickness (Franco et al. 2005). Working with crossbred animals (unpublished data), we found significant differences with respect to the water-holding capacity in meat when the interaction between $\mathrm{Hal}$ and $\mathrm{GH}$ genotypes was analyzed. Considering the correlation between fat thickness and lean meat percentage, as well as the correlation between the former and meat quality traits, we believe that a direct effect of the $\mathrm{GH}-\mathrm{D}_{2}$ allele in pork meat quality traits exists.

The breeds did not have any influence on drip loss, although there is a clear disequilibrium of genotypic frequencies among them, probably masking 
the true individual effects of the genes. It is probable that the $n n$ animals from Landrace and Large White breeds may be affecting the increasing variation in drip loss within these two breeds. It is important to notice that, at least one favorable and one unfavorable allele, for two genes, presented high frequency within the Large White $\left(N-D_{2}\right)$ and Piétrain $\left(n-D_{1}\right)$ breeds, while this is not observed for the Landrace (Table 3). The favorable effect of the $D_{1}$ allele (0.72) for lower drip loss, with the fixed frequency for the unfavorable $n$ allele (1.0) in the Piétrain breed, and the favorable effect of the $N$ allele (0.81) for lower drip loss, with unfavorable effect of the $D_{2}$ allele (0.75) in the Large White breed, may have contributed to the lack of differences between breeds, once they counterbalance the individual effect of each gene.

It seemed that the association of the $G H D_{2} D_{2}$ genotype with greater drip loss might be an influence of the Hal genotypes. However, when the genotypic combination is considered, there were a higher number of animals with $n n D_{1} D_{1}$ genotype (Table 3). Although under the negative influence of the $n n$ genotype on drip loss, there were significant differences among $G H$ genotypes for this trait, with $D_{1} D_{1}$ animals presenting the lowest drip loss values (Table 2). These data suggest the importance of the $G H$ polymorphism effect on the drip loss trait, despite the lower number of $n n D_{2} D_{2}$ animals (Table 3) that may have influenced the analysis.

Considering the sex, the $G H$ genotypic and allelic frequencies were exactly the same, between males and females. Even if we consider a possible interaction among $\mathrm{GH}, \mathrm{Hal}$ and sex, the results presented here clearly demonstrate the significant influence of $G H$ polymorphisms on the drip loss trait.

This is the first study that shows an association between DdeI GH genotypes and meat quality traits. Before that, only two other works have shown the association between this polymorphism with economic traits, but related to carcass and performance parameters (Putnova et al. 2001; Franco et al. 2005).

The association between $G H$ genotypes and meat quality showed here is reinforced by the major physiological role of $G H$ in carcass composition and muscle metabolism. Moreover, when the $G H$ gene is analyzed at the molecular level, the referred polymorphism can be observed at exon 2, which codes for the signal peptide. A transition from guanine to adenine at the codon 365 causes a missense mutation from arginine to glutamine (Vize and Wells 1987), thus altering its function. In general, alterations in the signal peptide sequence result in some impairment in protein synthesis or translocation to the endoplasmatic reticulum, which fatally results in phenotypic changes at several levels. Our conclusions are also supported by Plastow et al. (2005), who quoted the advantage of incorporating markers into selection programs when new markers are identified to replace older markers that begin to reach fixation. Moreover, they stated that once DNA markers for meat quality are identified they could be used in a wide range of breeds by changing allele 
frequencies through selection and/or introgression. The selection for specific genotypes may aid in the accomplishments of product specifications for fresh and processed pork products in a diverse market (Stalder et al. 2005).

When drip loss was considered for all main effects, only the breed effect presented no significant differences, although Piétrain animals tended to present higher drip loss, which was expected. The lower water-holding capacity of muscles is considered a major trait with important economical effects in the pig industry because of its association with carcass weight loss and lower yield of noble product output. The drip loss measure would be the best indicator for PSE status of meat, because it directly evaluates the protein denaturation level. However, the extended time needed to measure drip loss condition makes the use of this method unfeasible at the slaughter line.

The IMF is related to the carcass composition and meat quality. Although the results in this study did not show any association between genotypes and this trait, our measures are much lower than those showed elsewhere (Plastow et al. 2005; Correa et al. 2006), when a correlation between the IMF and treatments analyzed was demonstrated. This may indicate the strong selection to which these animals were submitted to improve the lean meat yield; but this may bring some damage to the organoleptic quality of the meat (Upnmoor 1997). On the other hand, our results agree with the data presented by Plastow et al. (2005), who also did not find differences of this trait among Piétrain, Landrace and Large White animals, although the leanest line, Piétrain, tended to have higher values of IMF in both studies.

\section{CONCLUSIONS}

Because the $n$ allele of $\mathrm{Hal}$ is fixed in the Piétrain line used in this work, there is a possibility that breed and genotype effects can be misinterpreted. Therefore, the results about lean meat percentage should be interpreted with caution. In spite of the detailed characterization of $\mathrm{Hal}$, as the major gene, influencing all of these traits in pigs, it is known that all of them are quantitative traits with polygenic control. Thus, the effect of the Hal gene over lean meat percentage may have been influenced by the Piétrain background. Results showed a great influence of sex over the majority of the analyzed traits, followed by breed effect, and lastly the genotype effect. This is expected, considering that all of the analyzed traits are quantitative with polygenic control. Another aspect to be considered is the relevance of knowing the characteristics of each breed better. Despite good characterization of maternal or paternal abilities of distinct pig lines, significant variations can still be found among lines of the same breed. Therefore, such variations should be considered in every genetic improvement program to be applied to establish the best 
mating strategy. Finally, the data presented here about $G H$ genotypes reinforce the possibility of its use in programs of marker-assisted selection.

\section{ACKNOWLEDGMENT}

We thank Rezende Alimentos S/A for providing the biological material used in this study.

\section{REFERENCES}

ANTUNES, R.C., BORGES, M., GOULART FILHO, L.R., SANCEVERO, A.B., SCHEID, I.R., FRANCO, M.M. and SANTANA, B.A.A. 2001. O efeito do genótipo HAL sobre o rendimento de carne em partes da carcaça de suínos cruzados. Tec Carnes 3(2), 7-15.

BAAS, T.J. 1996. Product quality - is it all in the genes? International Pig Topics 11, 7-11.

Band, G.O., GUIMARÃES, S.E.F., LOPES, P.S., SCHIERHOLT, A.S., SILVA, K.M., PIRES, A.V., BENEVENUTO JÃNIOR, A.A. and GOMIDE, L.A.M. 2005. Relationship between the porcine stress syndrome gene and pork quality traits of $\mathrm{F}_{2}$ pigs resulting from divergent crosses. Genet. Mol. Biol. 28(1), 88-91.

BRIDI, A.M., RÜBENSAM, J.M., NICOLAIEWSKY, S., LOPES, R.F.F. and LOBATO, J.F.P. 2003. Effect of the halothane genes and rearing systems on meat quality of pork. R. Bras. Zootec. 32(6), 13621370.

CAMERON, N.D. 1993. Selection for meat quality: Objectives and criteria. Pig News and Information 14, $161 \mathrm{~N}-168 \mathrm{~N}$.

CAMPBELL, R.G., STEELE, N.C., CAPERNA, T.J., MCMURTRY, J.P., SOLOMON, M.B. and MITCHELL, A.D. 1989. Interrelationships between sex and exogenous growth hormone administration on performance, body composition and protein and fat accretion of growing pigs. J. Anim. Sci. 67, 177-186.

CHRISTIAN, L.L. 1972. A review of the role of genetics in animal stress susceptibility and meat quality. In Proceedings of the Pork Quality Symposium, pp. 91-115, University of Wisconsin, Madison, WI.

COMMISSION INTERNATIONALE de L'ECLAIRAGE (CIE). 1976. Commission Internationale de l'Eclairage, 18th Session, 1975, CIE Publications, Vienna, Austria.

CORREA, J.A., FAUCITANO, L., LAFOREST, J.P., RIVEST, J., MARCOUX, M. and GARIÉPY, C. 2006. Effects of slaughter weight on 
carcass composition and meat quality in pigs of two different growth rates. Meat Sci. 72, 91-99.

DE VRIES, A.G., FAUCITANO, L., SOSNICKI, A. and PLASTOW, G.S. 2000. Influence of genetics on pork quality. In EAAP Publication, vol. 100, Abstracts, pp. 27-35, Zurich, Switzerland.

ENFÄLT, A.C., LUNDSTROM, K., KARLSSON, A. and HANSSON, I. 1997. Estimated frequency of the $\mathrm{RN}^{-}$allele in swedish Hampshire pigs and comparison of glycolytic potential, carcass composition, and technological meat quality among Swedish Hampshire, Landrace, and Yorkshire pigs. J. Anim. Sci. 75, 2924-2935.

ENFÄLT, A.C., SETH, G.V., JOSELL, A., LINDAHL, G., HEDEBROVELANDER, I., BRAUNSCHWEIG, M., ANDERSSON, L. and LUNDSTRÄM, K. 2006. Effects of a second mutant allele (V199I) at the PRKAG3 $(R N)$ locus on carcass composition in pigs. Livest. Sci. 99, 131-139.

FRANCO, M.M., ALMEIDA, J.F., DE SOUZA, G.R.L., ANTUNES, R.C. and GOULART, L.R. 2003. Development of a quantitative competitive reverse transcriptase polymerase chain reaction for the quantification of growth hormone gene expression in pigs. Genet. Mol. Biol. 26(1), 1318.

FRANCO, M.M., ANTUNES, R.C., SILVA, H.D. and GOULART, L.R. 2005. Association of PIT1, GH and GHRH polymorphisms with performance and carcass traits in Landrace pigs. J. Appl. Genet. 46(2), 195200.

FUJII, J., OTSU, K., ZORZATO, F., DE LEON, S., KHANNA, V.K., WEILER, J.E., O'BRIEN, P.J. and MACLENNAN, D.H. 1991. Identification of a mutation in porcine ryanodine receptor associated with malignant hyperthermia. Science 253, 448-451.

GELDERMANN, H., MULLER, E., BEECKMANN, P., KNORR, C., YUE, G. and MOSER, G. 1996. Mapping of quantitative trait loci by means of marker genes in $\mathrm{F}_{2}$ generations of Wild Boar, Piétrain, and Meishan pigs. J. Anim. Breed. Genet. 113, 381-387.

KNORR, C., MOSER, G., MULLER, E. and GELDERMANN, H. 1997. Associations of $G H$ gene variants with performance traits in $\mathrm{F}_{2}$ generations of European Wild Boar, Piétrain, and Meishan pigs. Anim. Genet. $28,124-128$.

LARSEN, N.J. and NIELSEN, V.H. 1993. Apa I and Cfo I polymorphisms in the porcine growth hormone gene. Anim. Genet. 24, 71.

LINDAHL, G., ENFÄLT, A.C., andersen, H.J. and LUNDSTRÄM, K. 2006. Impact of $R N$ genotype and ageing time on colour characteristics of the pork muscles longissimus dorsi and semimembranosus. Meat Sci. 74, 746-755. 
MOLLER, A.J. and IVERSEN, P. 1993. Elements in the concept of pig meat quality. In 44th Annual Meeting of the European Association for Animal Production, pp. 16-19, Aarhus, Denmark.

NIELSEN, V.H. and SORENSEN, D. 1998. Overdominance at the growth hormone gene for daily gain in pigs. In CD ROM from 6th World Congress on Genetics Applied to Livestock Production, January 11-16, 1998, pp. 304-307, Armidale, Australia.

PLASTOW, G.S., CARRIÓN, D., GIL, M., GARCÓA-REGUEIRO, J.A., FONTI FURNOLS, M., GISPERT, M., OLIVER, M.A., VELARDE, A., GUÀRDIA, M.D., ET AL. 2005. Quality pork genes and meat production. Meat Sci. 70, 409-421.

PUTNOVA, L., KRENKOVA, L., VRTKOVA, I., DVORAK, J., PIETRUSZKA, A. and CZARNECKI, R. 2001. Association of the DdeI growth hormone gene polymorphism with some performance traits in Polish Large White and Czech Large White $\times$ Polish Large White pigs. J. Appl. Genet. 42(3), 317-324.

SAS. 1992. SAS User's Guide: Statistical Analysis Systems, SAS Institute, Cary, NC.

SCHELLANDER, K., PELI, J., KNEISSL, F., SCHMOLL, F. and MAYR, B. 1994. Variation of the growth hormone gene in RYR 1 genotyped Austrian pig breeds. J. Anim. Breed. Genet. 111, 162-166.

SELLIER, P. 1995. Genetics of pork quality. In I Conferência internacional sobre ciência e tecnologia de produção e industrialização de suínos, pp. 1-35, CTC/ITAL, Campinas, Brasil.

SELLIER, P. 1998. Genetics of meat and carcass traits. In The Genetics of the Pig (M.F. Rothschild and A. Ruvinsky, eds.) pp. 463-510, CAB International, Wallingford, U.K.

SELLIER, P. and MONIN, G. 1994. Genetics of pig meat quality: A review. J. Muscle Foods 5, 187-219.

SOARES, A.L., IDA, E.I., OLIVO, R. and SHIMOKOMAKI, M. 1998. Benefícios da utilização da vitamina $\mathrm{E}$ na dieta dos animais para o controle da cor e rancidez das carnes. Revista Nacional da Carne 259, $18-22$.

SOCHA, T.E. 1997. Meat quality - the future of pork production. Young Swine Conference, 95-99.

STALDER, K.J., ROTHSCHILD, M.F. and LONERGAN, S.M. 2005. Associations between two gene markers and indicator traits affecting fresh and dry-cured ham processing quality. Meat Sci. 69, 451-457.

SWATLAND, H.J. 1995. Online Evaluation of Meat, p. 343, Technomic Publishing, Lancaster, PA.

UPNMOOR, I. 1997. Marmorização da carne suína. Suinocultura Industrial $126,30-32$. 
VIZE, P.D. and WELLS, J.R.E. 1987. Isolation and characterization of the porcine growth hormone gene. Gene 55, 339-344.

WALSTRA, P. and MERKUS, G.S.M. 1995. Procedure for Assessment of the Lean Meat Percentage as a Consequence of the New EU Reference Dissection Method in Pig Carcass Classification, DLO-Research Institute for Animal Science and Health (ID-DLO), Zeist, The Netherlands. 